\title{
Applications of Hydrogeochemical Modeling to Assessment Geochemical Evolution of the Pliocene Aquifer System in Wadi EI Natrun Area, Western Desert, Egypt
}

\author{
Mohamed Kamel Fattah \\ Department of Evaluation of Natural Resources, Environmental Studies and Research Institute, University of Sadat City, Sadat, Egypt \\ Email address: \\ mohamed.fattah $a$ esri.usc.edu.eg, kamelhydro90@yahoo.com

\section{To cite this article:} \\ Mohamed Kamel Fattah. Applications of Hydrogeochemical Modeling to Assessment Geochemical Evolution of the Pliocene Aquifer \\ System in Wadi El Natrun Area, Western Desert, Egypt. Hydrology. Vol. 5, No. 1, 2017, pp. 7-14. doi: 10.11648/j.hyd.20170501.12
}

Received: December 25, 2016; Accepted: January 16, 2017; Published: February 24, 2017

\begin{abstract}
Pliocene aquifer is the main source of water in the study area (Wadi El Natroun area), Western desert, Egypt. Area of the study was divided into three sectors (South, Centre and North). There is a deterioration of quality and increase salinity in water, salinity ranges between 300and $6822 \mathrm{mg} \backslash 1$. The target of this study explaining and clarify the evolution mechanism of water in the Pliocene aquifer through three former sectors to understand the mechanism of the hydrochemical processes by applying hydrogeochemical - environmental program (Netpath Program) which performed for three groundwater paths (A-A'), (B-B) and (C-C') sector and it used to explain net geochemical mass-balance reactions which occurs between initial and final water point. The study showed that the process of dissolution of chlorides and sulphate salts ( halite, gypsum and anhydrite) are the most common effected process, in contrast, deposition of carbonate salts and bicarbonate in the three sectors in area of the study, there is a significant effect of continuous cationic exchange between water and surrounding rocks leading to deterioration of water types and increasing salinity in the direction of water flow from East to West, also water quality change from bicarbonate water type in the east (initial points) to sulphate and chlorides water type in the west direction (final points) and these process represent late stage of mineralization.
\end{abstract}

Keywords: Geochemical Evolution, Netpath, Pliocene Aquifer, Wadi El Natrun

\section{Introduction}

Wadi El Natrun occupies a portion of the Western Nile Delta region (Fig. 1). It lies between longitude $30^{\circ} 04^{\prime}$ and $30^{\circ} 30^{\prime} \mathrm{E}$ and latitudes, $30^{\circ} 16^{\prime}$ and $30^{\circ} 30^{\prime} \mathrm{N}$. The study area covers an area of about67608Feddans or $281 \mathrm{~km}^{2}$. El- Abd, E. A. (2005).

The objective of this paper is to expound and examine the evolution mechanisms of a hydrogeochemical approach in the Pliocene aquifer. NETPATH model was used to explain net geochemical mass-balance reactions between initial and final water point which occurred within dissolution and precipitation, hypothetical salts, saturated index and to explain water-rock interaction of the local groundwater in the study area the Pliocene aquifer. Geochemical modeling was performed for three groundwater paths (South, Centre and North path 1 (A-A'), path 2(B-B') and path 3 (C-C')

\section{Material and Methods}

Complete chemical analysis of 15 groundwater points, table (1), the analyses occurred according to the methods adopted by ASTM (2002). The analyses conducted both in the field and laboratory include total dissolved solids (TDS), measurement of $\mathrm{pH}$, electrical conductivity (EC), concentrations of $\mathrm{Ca}^{+2}, \mathrm{Mg}^{+2}, \mathrm{Na}^{+}$and $\mathrm{K}^{+}$as cations, $\mathrm{CO}_{3}^{-2}$, $\mathrm{HCO}_{3}^{-}, \mathrm{SO}_{4}^{-2}$ and $\mathrm{Cl}^{-}$as anions. Also, (Plummer et al. (1994), discuses saturation indices were calculated with the help of NETPATH model computer program, A global positioning system (GPS) program. Garment 12 are using for determine the location and the elevation readings in this study. The NETPATH computer model program was used to simulate the major hydrogeochemical reactions contributing to explain the evolution of groundwater chemistry in Pliocene aquifer at area of the study (Wadi El Natrun.). Plummer et al. (1994), 
described the model in detail;. (Lyon and Bird, 1995; and Soulsby et al., 1998.).

Table 1. Chemical analyses of the groundwater wells in the study area.

\begin{tabular}{|c|c|c|c|c|c|c|c|c|c|c|c|}
\hline \multirow{2}{*}{ Sample No. } & \multirow{2}{*}{ EC M.mohs/cm } & \multirow{2}{*}{ TDS Mg/l } & \multirow{2}{*}{ PH } & \multicolumn{2}{|c|}{ Cations (ppm) } & \multicolumn{6}{|c|}{ Anions (ppm) } \\
\hline & & & & $\mathbf{K}$ & $\mathbf{N a}$ & Mg & Ca & $\mathrm{Cl}$ & $\mathrm{SO}_{4}$ & $\mathrm{HCO}_{3}$ & $\mathrm{CO}_{3}$ \\
\hline 1 & 1.64 & 1050 & 8.36 & 40 & 290 & 10.7 & 12.8 & 261 & 200 & 205 & 8 \\
\hline 2 & 0.64 & 410 & 8.32 & 8 & 102 & 4.84 & 16 & 55 & 90 & 145 & 0 \\
\hline 3 & 0.94 & 602 & 8.25 & 13 & 143 & 12.15 & 40 & 135 & 90 & 170 & 32 \\
\hline 4 & 1.07 & 688 & 7.32 & 7 & 180 & 2.43 & 40 & 140 & 95 & 260 & 0 \\
\hline 5 & 1.08 & 691 & 7.75 & 12 & 165 & 4.86 & 32 & 110 & 135 & 215 & 16 \\
\hline 10 & 4.98 & 3187 & 8.03 & 44 & 1061 & 9.72 & 64 & 1230 & 670 & 160 & 0 \\
\hline 11 & 2.41 & 1542 & 8.31 & 26 & 450 & 9.72 & 32 & 414 & 400 & 160 & 12 \\
\hline 21 & 1.88 & 1206 & 7.48 & 13 & 380 & 9.72 & 16 & 296 & 380 & 100 & 16 \\
\hline 33 & 0.97 & 621 & 7.48 & 27 & 130 & 16.52 & 16 & 90 & 90 & 249 & 0 \\
\hline 34 & 0.14 & 930 & 7.55 & 17 & 250 & 19.44 & 32 & 300 & 200 & 111 & 0 \\
\hline 30 & 0.47 & 302 & 7.5 & 6 & 51 & 4.86 & 32 & 50 & 61 & 100 & 0 \\
\hline 36 & 0.12 & 800 & 7.5 & 12 & 195 & 3.4 & 62.4 & 250 & 128 & 150 & 0 \\
\hline 37 & 2.00 & 1280 & 7.55 & 36 & 271 & 10.7 & 128 & 410 & 310 & 100 & 10 \\
\hline 39 & 10.6 & 6822 & 7.48 & 32 & 2360 & 6.8 & 144 & 3000 & 1100 & 227 & 0 \\
\hline 40 & 4.14 & 2650 & 7.55 & 7 & 617 & 11.66 & 96 & 831 & 360 & 110 & 0 \\
\hline
\end{tabular}

\section{Geological and Hydrogeological Aspects}

The Pliocene aquifer is located in the western side of the Nile River at Wadi El Natrun area. The Pliocene sediments act as a good aquifer in area of the sudy at Wadi El Natrun and northwest of it. The Pliocene sediments are mostly built up of clays underlying the Quaternary aquifer, and hence they represent the main aquiclude horizon in this area. The Pliocene sediments in Wadi El Natrun are mainly affected by several faults which facilitate the connection between The Pliocene and the Quaternary aquifers. These faults are trending NW-SE direction and bounding Wadi El Natrun from the east with downthrown side to the northeast. So the Quaternary aquifer lies in the front of the Pliocene one in the east. Also Wadi El Natrun is bounded from the south and west by clysmic NW-SE faults with downthrown side to the northeast. So the Miocene aquifer is located in the front of the Pliocene facilitating the hydraulic connection between them El- Abd, E. A. (2005).

\subsection{Depth to Water and Groundwater Flow}

The depth to water of the Pliocene aquifer ranges between $20 \mathrm{~m}$ to $30 \mathrm{~m}$ outside the wadi El Natrun and less than $10 \mathrm{~m}$ to flowing in the surface inside Wadi El Natrun. The Groundwater flows from northeast and southeast to southwest and northwest i.e. to Wadi El Natrun area. Also local cones of depressions spread in the western and southwestern side of Wadi El Natrun depression. Such local trends of groundwater movements are mainly attributed to the over exploitation of groundwater to irrigate the newly reclaimed lands. The aquifer in area of the study is mainly recharged from the Quaternary and Miocene aquifers through the hydraulic connection. The water of the latter aquifers are laterally flowing towards depression area (Wadi El Natrun), which acts as natural discharging area. The recharge to the Pliocene aquifer, which equals the permissible extraction rate under any condition of future reclamation, was estimated by TRIWACO model to be $128040 \mathrm{~m}^{3} /$ day (Diab et al, 2002). The Pliocene aquifer at wadi El Natrun receives other recharge from the southern portion of the Nile Delta through Wadi El Farigh (Abdel Baki, 1983).

\subsection{General Hydrogeochemistry}

The salinity contents ranging from $300 \mathrm{mg} / \mathrm{l}$ in well no. 30 at the south east to $6822 \mathrm{mg} / \mathrm{l}$ in well no.39 (Clay Quarries) at the midele part of wadi el Natrun, tables 1 and 2 the salinity increase from east to west in the same direction of water flow. The groundwater of the Pliocene aquifer is mainly belongs to brakish saline water( Fig. 2), $\mathrm{Na}^{+}$is the major cation in the groundwater, followed by $\mathrm{Ca}^{2+}$ and $\mathrm{Mg}^{2+}$; major anions are $\mathrm{Cl}-\mathrm{SO}_{4}{ }^{2}-$, followed by $\mathrm{HCO}^{3}{ }^{-}$. Hydrochemical types are mostly $\mathrm{Cl} \mathrm{SO}_{4}-\mathrm{Na} \cdot \mathrm{Ca}-\mathrm{Mg}$ type and the $\mathrm{HCO}_{3} \cdot \mathrm{Cl}-\mathrm{Na} \cdot \mathrm{Ca}$ type.

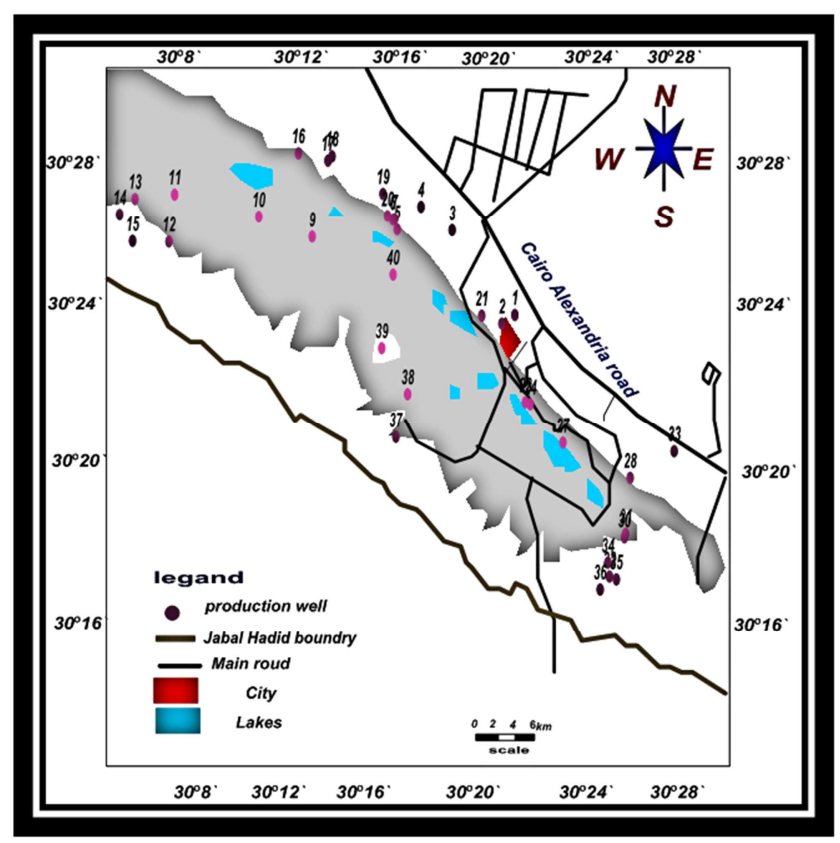

Figure 1. Wells location map. 


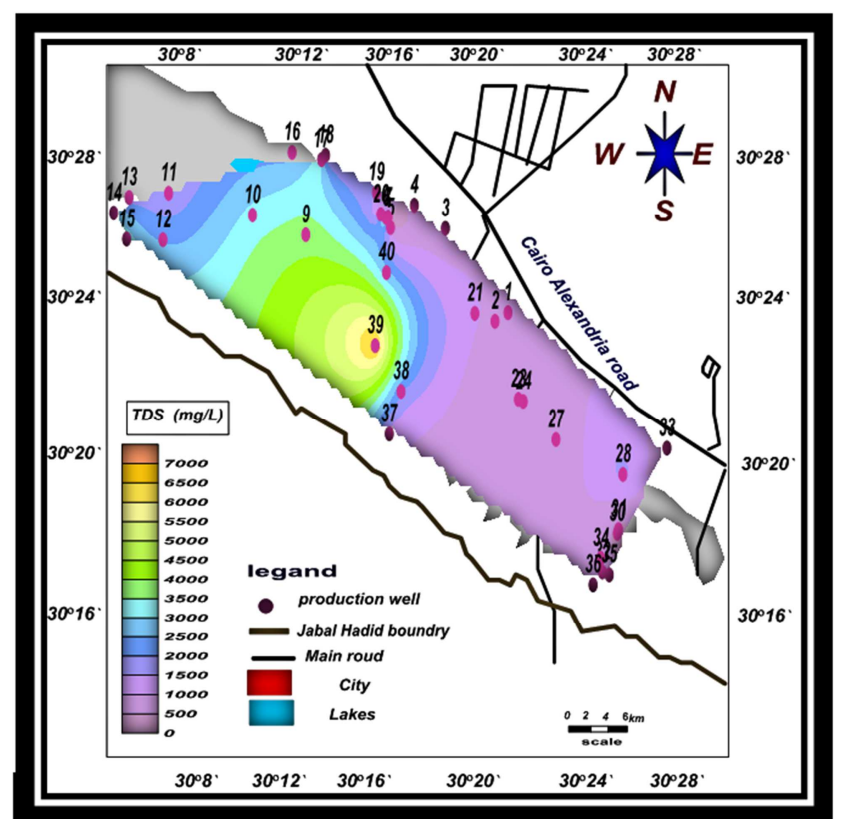

Figure 2. Salinity distribution contour map of the Pliocene aquifer at WadiEl Natrun.

Table 2. Chemical analyses of selective wells (cations and anions by epm) in the study area.

\begin{tabular}{llllllll}
\hline Well No. & TDS & $\mathbf{K}^{+}+\mathbf{N a}^{+}$ & $\mathbf{M g}^{+2}$ & $\mathbf{C a}^{+2}$ & $\mathbf{C l}^{-}$ & $\mathbf{S O}_{4}{ }^{-2}$ & $\begin{array}{l}\mathbf{H C O}_{3}^{-} \\
+\mathbf{C O}_{3}{ }^{-2}\end{array}$ \\
\hline 5 & 691 & 7.48 & 0.4 & 1.6 & 3.1 & 2.8 & 4.06 \\
9 & 3712 & 60.51 & 0.6 & 1.2 & 45.07 & 13.42 & 3.72 \\
12 & 2432 & 33.63 & 1.4 & 2.8 & 21.69 & 12.98 & 3.15 \\
33 & 621 & 6.34 & 1.36 & 0.8 & 2.54 & 1.88 & 4.08 \\
27 & 627 & 7.57 & 0.2 & 0.8 & 3.24 & 1.98 & 3.44 \\
37 & 1280 & 12.6 & 0.88 & 6.40 & 11.55 & 6.46 & 1.97 \\
2 & 410 & 4.64 & 0.4 & 0.8 & 1.55 & 1.88 & 2.38 \\
21 & 1206 & 16.85 & 0.8 & 0.8 & 8.34 & 7.91 & 2.17 \\
39 & 6822 & 103.43 & 0.56 & 7.2 & 84.5 & 22.92 & 3.72 \\
\hline
\end{tabular}

\section{Environmental Impacts on Hydrogeochemical Mass-Balance Reactions (Geochemical Modeling)}

The NETPATH programs used to evaluate the subsurface geochemical processes and provides an indication of the reaction potential of the hydrogeochemical system, also it is used to perform a variety of aqueous geochemical calculations including the saturation indices (SI) of the major mineral phases, and water mixing models, Park, et al. 2005. NETPATH (Plummer, et al. 1988) was used to environmental simulate net geochemical mass-balance reactions which occurred between initial and final water point along flow path. NETPATH was used to perform a variety of aqueous geochemical calculations including; the saturation indices (SI) of the major mineral phases, testing of water corrosively, influencing of the River Nile on the groundwater and to apply water mixing models Bertolo, R., et al. 2006. Geochemical models are calculation tools to calculate chemical reactions in groundwater system, such as dissolution and precipitation of solids, ion exchange and sorption by clay minerals. The two basic approaches to modeling aquifer geochemical interactions have been termed inverse and forward models Sun, Y. Q., et al. 2007. The program calculates the saturation indices of Calcite, Aragonite, Dolomite, halite, Siderite, Rhodochr, Gypsum, Anhydrite, Hematite, Goethite, Vivianit, $\mathrm{H}_{2}$ Gas and Partial carbon dioxide $\mathrm{P}-\mathrm{CO}_{2}$. Geochemical modeling was performed for three groundwater paths.

\section{Results and Discussion}

\subsection{Cation Exchange Process}

The cation exchange playing an important roles in explain the process of evolution of hydrogeochemical composition, Whether the ion-exchange reaction can be expressed by the trend of the milligram equivalent (epm) concentration ratio of $\mathrm{Ca}^{2+}$ to $\mathrm{Na}^{+}\left\{\mathrm{N}\left(\mathrm{Ca}^{2+}\right) / \mathrm{N}\left(\mathrm{Na}^{+}\right)\right\}$, from the start (initial) water sample to the end water sample. If $\mathrm{N}\left(\mathrm{Ca}^{2+}\right) / \mathrm{N}\left(\mathrm{Na}^{+}\right)$ decreases, $\mathrm{Ca}^{2+}$ concentration in the water exchange with $\mathrm{Na}^{+}$ in the clay. If $\mathrm{N}\left(\mathrm{Ca}^{2+}\right) / \mathrm{N}\left(\mathrm{Na}^{+}\right)$increases, $\mathrm{Na}^{+}$in the water exchange with $\mathrm{Ca}^{2+}$ in the clay (Sun, Y. Q et al. 2007;and Wang, $\mathrm{P}$. $\mathrm{M}$ et al. 2010). From the $\mathrm{N}\left(\mathrm{Ca}^{2+}\right) / \mathrm{N}\left(\mathrm{Na}^{+}\right)$variation diagrams (Fig. 3) we can notes that $\mathrm{N}\left(\mathrm{Ca}^{2+}\right) / \mathrm{N}\left(\mathrm{Na}^{+}\right)$shows an upward trend through path $1(\mathrm{AAl})$ where, $\mathrm{N}\left(\mathrm{Ca}^{2+}\right)$ $/ \mathrm{N}\left(\mathrm{Na}^{+}\right)$increases, there may be exchange between $\mathrm{Na}^{+}$in the water and $\mathrm{Ca}^{2+}$ in the clay but a downward trend along path2 $(\mathrm{BB} \backslash)$ and path $3(\mathrm{CC})$ ). Therefore, the cation exchange process may occur during groundwater flow along both pathes $1(\mathrm{AA} \backslash)$ path $2(\mathrm{BB} \backslash)$ and path $3(\mathrm{CCl})$.

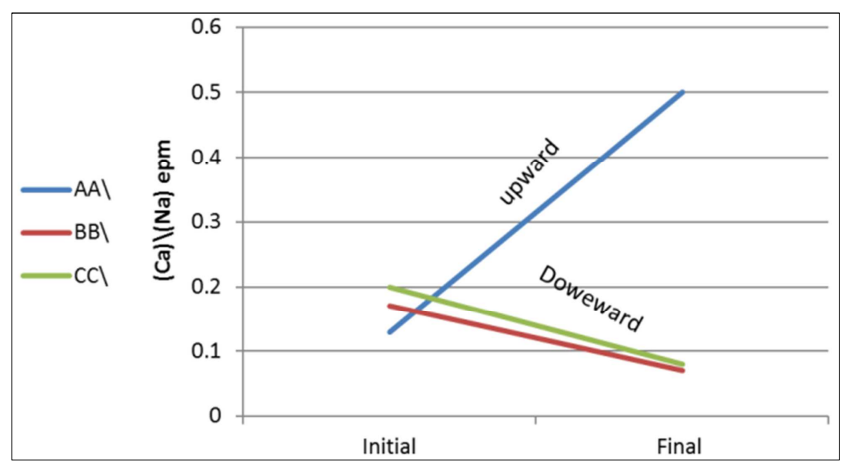

Figure 3. $N(\mathrm{Ca}) \mid N(\mathrm{Na})$ variation in simulated paths.

\subsection{Calculation of Saturation Index for the Minerals}

The saturation index method was used to explain the process of dissolution or precipitation trend. The saturation index $\mathrm{Si}$ is used indicator in hydrogeochemical study. It describes the saturation status of minerals in the groundwater The positive signs of the saturation index (SI) mean that the solution is supper saturated and consequently precipitation processes occurred. While the negative signs reflect that the solution is sub-saturated and dissolution processes occurred, zero value means that the solution is in equilibrium state (Luo et al. 2008; and Sharif, M. U., et al. 2008). The saturation index $(\mathrm{SI})$ is expressed as: $\mathrm{SI}=\log (\mathrm{IAP} / \mathrm{K})$. 
Where IAP is the relevant ion activity product in a mineral dissolution reaction, and $\mathrm{K}$ is the equilibrium constant of mineral dissolution at a certain temperature (Plummer et al., 1994) and Xu, Z. H., (2009).

Table 3. Mineral equilibrium and saturation indices of minerals that present in groundwater of Pliocene aquifer.

\begin{tabular}{|c|c|c|c|c|c|c|c|c|}
\hline Path number & Well No. & Calcite & Aragonite & Dolomite & Gypsum & Anhydrite & TDS & Ionic sequance \\
\hline \multirow{2}{*}{ Path 1 A_A South } & 33 & 0.381 & 0.237 & 1.128 & -2.304 & -2.524 & 621 & \multirow{2}{*}{$\left.\mathrm{HCO}_{3}>\mathrm{Cl}>\mathrm{SO}_{4}\right)\left(\mathrm{Cl}>\mathrm{SO}_{4}>\mathrm{HCO}_{3}\right)$} \\
\hline & 37 & 0.341 & 0.197 & -0.050 & -1.072 & -1.292 & 1280 & \\
\hline \multirow{2}{*}{ Path 2 B_B } & 2 & 0.184 & 0.4 & 0.197 & -2.233 & -2.453 & 410 & \multirow{2}{*}{$\mathrm{HCO}_{3}>\mathrm{Cl}>\mathrm{SO}_{4}\left(\mathrm{Cl}>\mathrm{SO}_{4}>\mathrm{HCO}_{3}\right)$} \\
\hline & 39 & 0.0587 & 0.0443 & 0.198 & -0.892 & -1.109 & 6822 & \\
\hline \multirow{2}{*}{ Path 3 C_C North } & 5 & -0.126 & -0.27 & -0.725 & -1.841 & -2.061 & 691 & \multirow{2}{*}{$\left.\mathrm{HCO}_{3}>\mathrm{Cl}>\mathrm{SO}_{4}\right)\left(\mathrm{Cl}>\mathrm{SO}_{4}>\mathrm{HCO}_{3}\right)$} \\
\hline & 12 & 0.255 & 0.111 & 0.336 & -1.264 & -1.483 & 2432 & \\
\hline
\end{tabular}

Positive sign $(+)$ : Supersaturation and precipitation process.

Negative sign (-0): Undersaturation and dissolution process.

From table (3), the results obtained from WATEQF have established that groundwater samples collected from the Pliocene aquifer are seen to be supersaturated in Calcite, Aragonite as well as Dolomite with saturation indices range from 0.008 to 1.432 for calcite, 0.03 to 1.289 for Aragonite, 0.02 to 3.034 for Dolomite On the other hand, all of the samples were subsaturated in Gypsum with saturation indices between -2.565 and -0.892 , Anhydrite with saturation indices -2.785 and $-1.109, \mathrm{H}_{2}$ gas with saturation indices between 19.92 to -14.64 and $\mathrm{PCO}_{2}$ with saturation indices between 5.256 to -1.925 (Table 3 ) we can see that the minerals equilibrium along simulated path 1 have the same precipitation or dissolution trend as those along simulated paths 2 while simulated path 3 is different. Gypsum and anhydrite along the simulated paths showed unsaturated status with a dissolution trend, while the calcite, aragonite and dolomite (carbonate minerals) have supersaturated with a precipitation trend. According to water quality analysis results. On simulated path 1, the TDS of water samples at the initial point was $621 \mathrm{mg} / \mathrm{L}$, and it increased to $1280 \mathrm{mg} / \mathrm{L}$ at the end point of the water sample. The hydrochemicalwater type varied from the $\mathrm{HCO}_{3}>\mathrm{Cl}>\mathrm{SO}_{4}$ type to the $(\mathrm{Cl}>$ $\mathrm{SO}_{4}>\mathrm{HCO}_{3}$ ) type, which shows that from east to west, and from downward to upward.

Along simulated path 2, the TDS varied from $691 \mathrm{mg} / \mathrm{L}$ at the initial point to $2432 \mathrm{mg} / \mathrm{L}$ at the end point, and the hydrochemical type was the $\mathrm{HCO}_{3}$.type at the initial point and changed to the $\mathrm{SO}_{4}$ and chlorid- type at the end point, which also indicates that dissolution effects along simulated path 2 are strong and water quality gradually deteriorates. Along simulated path 3, the TDS varied from $410 \mathrm{mg} / \mathrm{L}$ at the initial point to $6822 \mathrm{mg} / \mathrm{L}$ at the end point, and the hydrochemical type varies from $\mathrm{HCO}_{3}$.type at the initial point to the $\mathrm{SO}_{4}$ and chloride- type at the end point, which also indicates that dissolution effects along all simulated path 1,2 and 3 are strong and water quality gradually deteriorates and describes the occurrence of advanced stage of mineralization

\subsection{Mass Balance Simulation (Model Results)}

The results obtained from NETPATH have been established table (4) The net geochemical mass-balance reactions between initial and final waters of three Profiles selected along the groundwater flow path of the Plioocene aquifer (Fig. 4.) was preceded, Sodium, Potassium, Calcium, magnesium, Chloride, Sulfur, Carbon, iron, Manganese, Nitrogen and Phosphorus were introduced into the model as constraints. Na-montmorillonite, K-montmorillonite, Camontmorillonite, Dolomite, Sodium Chloride, Gypsum, Aragonite, Goethite, Hematite and Exchange were selected as interactive phases of the aquifer, table (5) equations of mineral and gas of the inter active phases. The results of mass - balance transfer along groundwater flow path are presented in table (6) and figures 5, 6, and 7.

Table 4. Shows the constraints and Phases used by DB and NETPATH in the Pliocene aquifer in the study area.

\begin{tabular}{lll}
\hline NO. & CONSTRAINTS & PHASES \\
\hline 1 & Sodium & Na-Mont. \\
2 & Potassium & K-Mont. \\
3 & Calcium & Ca-Mont. \\
4 & Magnesium & Dolomite \\
5 & Chloride & Sodium Chloride \\
6 & Sulfur & Gypsum \\
7 & Carbon & Aragonite \\
8 & Iron & Geothite \\
9 & Manganese & Rhodochr \\
10 & Nitrogen & NH \\
11 & Phosphorus & Vivianit \\
\hline
\end{tabular}

Table 5. Equations of mineral and (gas) dissolution.

\begin{tabular}{ll}
\hline Mineral & Equation of mineral (gas)dissolution \\
\hline Gypsum & $\mathrm{CaSO}_{4} \cdot 2 \mathrm{H}_{2} \mathrm{O}=\mathrm{Ca}^{2+}+2 \mathrm{SO} 4-+2 \mathrm{H}_{2} \mathrm{O}$ \\
Sodium montmorillonite & $3 \mathrm{Na}_{0.33} \mathrm{Al}_{2.33} \mathrm{Si}_{3.67} \mathrm{O}_{10}(\mathrm{OH})_{2}+30 \mathrm{H}_{2} \mathrm{O}+6 \mathrm{OH}^{-}$ \\
& $\mathrm{Na}^{+}+7 \mathrm{Al}(\mathrm{OH})_{4}-+11 \mathrm{H}_{4} \mathrm{SiO}_{4}$ \\
Aragonite & $\mathrm{CaCO}_{3}=\mathrm{Ca}^{2+}+2 \mathrm{CO}_{3}^{-}$ \\
Calcite & $\mathrm{CaCO}_{3}=\mathrm{Ca}^{2+}+2 \mathrm{CO}_{3}^{-}$ \\
Halite & $\mathrm{NaCl}=\mathrm{Na}^{+}+\mathrm{Cl}^{-}$ \\
Dolomite & $\left.\mathrm{CaMg}^{-} \mathrm{CO}_{3}\right)_{2}=\mathrm{Ca}^{2+}+\mathrm{Mg}^{2+}+2 \mathrm{CO}_{3}^{-}$ \\
$\mathrm{CO}_{2}$ & $\mathrm{CO}_{2}+\mathrm{H}_{2} \mathrm{O}=\mathrm{H}_{2} \mathrm{CO}_{3}$ \\
Cation exchange & $2 \mathrm{NaX}_{+} \mathrm{Ca}^{2+} \leftrightarrow 2 \mathrm{Na}^{+}+\mathrm{CaX}_{2}$ \\
\hline
\end{tabular}




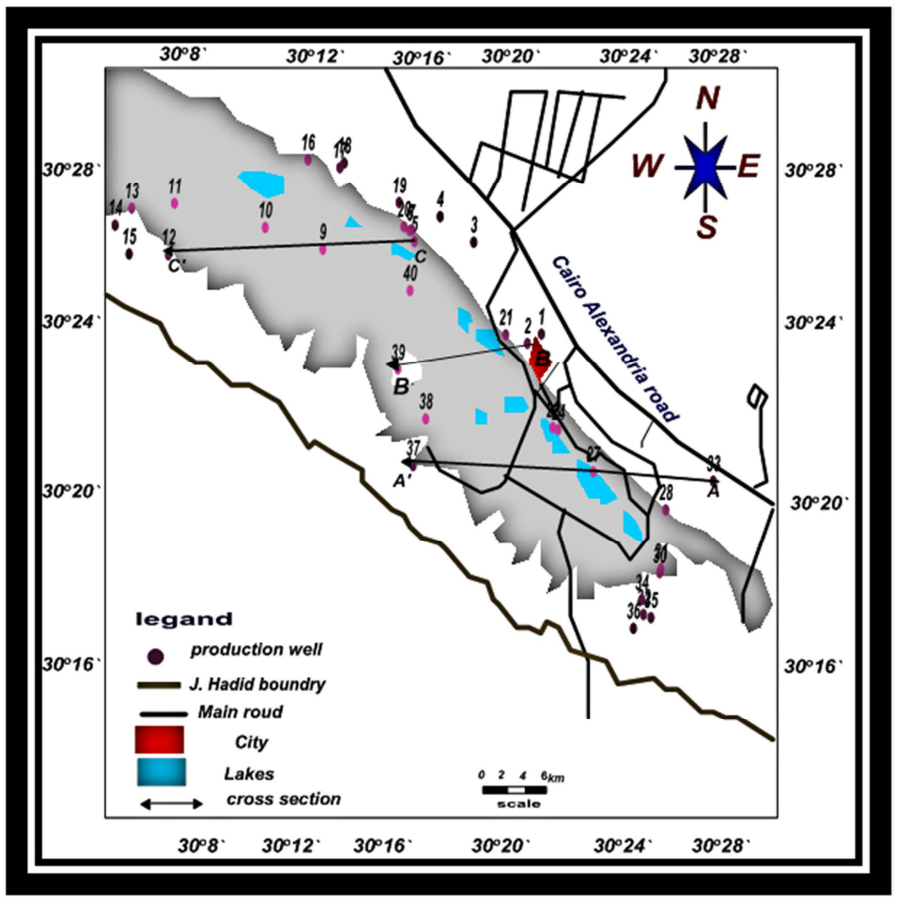

Figure 4. Profiles selected along the groundwater flow path in groundwater wells of the Pliocene aquifer in the study area.

Table 6. Minerals results of mass balance transfer (NETPATH MODEL) along a flow path in groundwater wells of the Pliocene aquifer in the study area.

\begin{tabular}{|c|c|c|c|c|c|c|c|c|c|c|}
\hline Path number & Well No. & K-Mon & Calcite & Dolomite & Gypsum & Sodium Chloride & Aragonite & Ca-Mon & Hematite & Exchange \\
\hline Path 1A_A South & $33 \& 37$ & 0.69976 & -1.773 & -0.218 & 2.29381 & 9.0395 & -1.77352 & -0.0009 & -0.0004 & -2.49 \\
\hline Path 2 B_B Middle & $2 \& 39$ & 1.876 & 1.39 & 0.08248 & 10.5933 & 83.65 & 1.396 & -7.28 & 0.0053 & 7.637 \\
\hline Path 3 C_C Morth & $5 \& 12$ & 1,2446 & -1.9 & 0.5009 & 5.095 & 18.667 & -1.919 & -0.0107 & -0.00529 & 3.5795 \\
\hline
\end{tabular}

Positive sign (+): dissolution of mineral (m. mole $/ \mathrm{Kg}$ )

Negative sign (-): Precipitation of mineral (m. mole $/ \mathrm{Kg})$

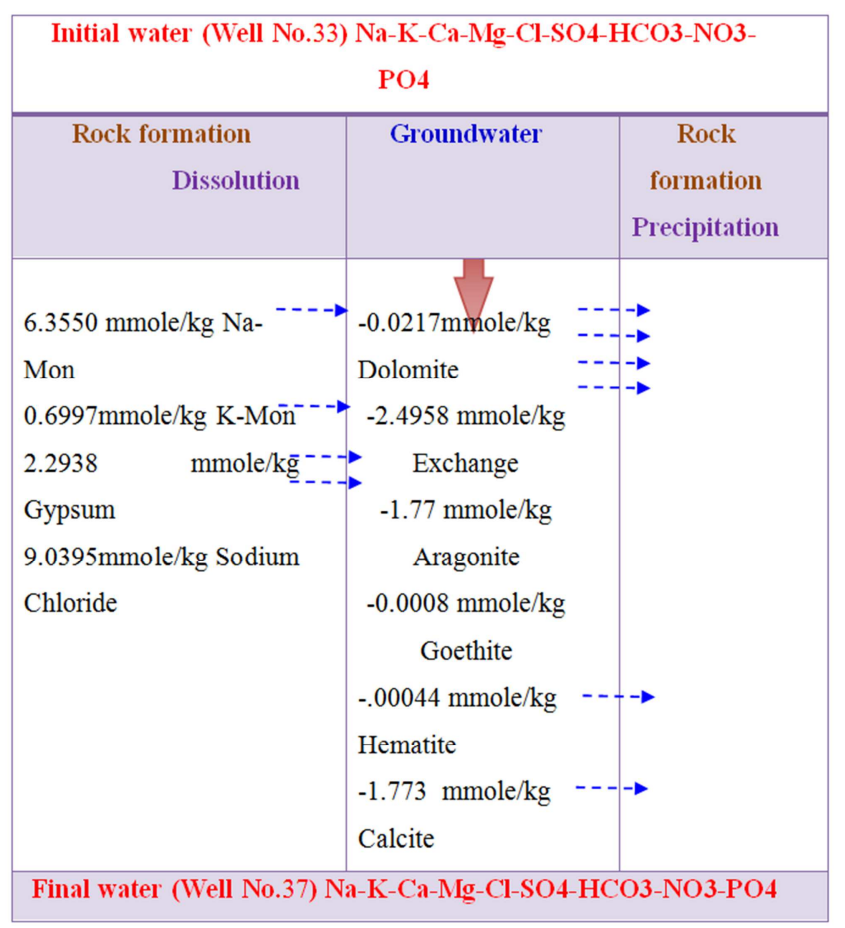

Figure 5. Mass balance transfers of profileAA $\mid$ along a flow path in groundwater wells of the Pliocene aquifer in the study area.

\begin{tabular}{|c|c|c|}
\hline $\begin{array}{l}\text { Rock formation } \\
\text { Dissolution }\end{array}$ & Groundwater & $\begin{array}{c}\text { Rock } \\
\text { formation } \\
\text { Precipitati } \\
\text { on }\end{array}$ \\
\hline 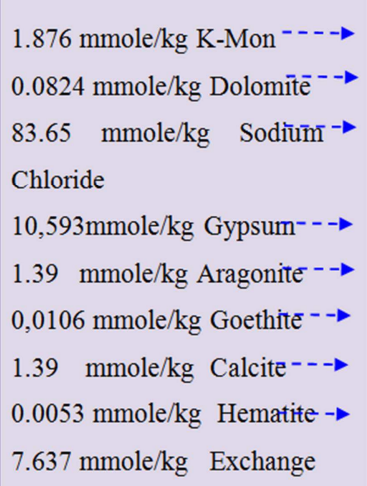 & $\begin{array}{l}-7.2859 \mathrm{Ca}- \\
\text { Mont }\end{array}$ & $\rightarrow$ \\
\hline
\end{tabular}

Figure 6. Mass balance transfers of profile $B B \backslash$ along a flow path in groundwater wells of the Pliocene aquifer in the study area. 


\begin{tabular}{|c|c|c|}
\hline \multicolumn{3}{|c|}{ Initial water (Well No.5) Na-K-Ca-Mg-Cl-SO4-HCO3-NO3-PO4 } \\
\hline $\begin{array}{l}\text { Rock formation } \\
\text { Dissolution }\end{array}$ & Groundwater & $\begin{array}{c}\text { Rock } \\
\text { formation } \\
\text { Precipitation }\end{array}$ \\
\hline $1.2446 \mathrm{mmole} / \mathrm{kg} \mathrm{K}-\mathrm{Mon}^{-}=$ & & \\
\hline $0.5009 \quad \mathrm{mmole} / \mathrm{kg}^{-}$ & $\rightarrow-1.919 \mathrm{mmole} / \mathrm{kg}$ & $\rightarrow$ \\
\hline Dolomite & $\rightarrow$ Aragonite & \\
\hline $\mathrm{mmole} / \mathrm{kg}$ & $-0.0107 \mathrm{mmole} / \mathrm{kg}$ & $\rightarrow$ \\
\hline Gypsum & Goethite & \\
\hline $18.6675 \mathrm{mmole} / \mathrm{kg}$ & $-1.9 \mathrm{mmole} / \mathrm{kg}$ & $\rightarrow$ \\
\hline Sodium Chloride & Calcite & \\
\hline $3.5795 \mathrm{mmole} / \mathrm{kg}$ & $-0,00529 \mathrm{mmole} / \mathrm{kg}$ & $\rightarrow$ \\
\hline Exchange & Hematite & \\
\hline
\end{tabular}

Figure 7. Mass balance transfers of profile $C C \backslash$ along a flow path in groundwater wells of the Pliocene aquifer in the study area.

\section{The following can be concluded:}

a) Profile (AAl): The results of mass-balance transfer along this profile fig. (5), reflect precipitation of -1.7735 mmole Aragonite, -0.00089 mmole Goethite, -1.773 Calcite. -0.2178 Dolomite, -2.49588 Exchange and -0.00044 Hematite. while dissolution of 6.3550 mmole Na-Mont, 0.6997 mmole K- mon, 2.2938 mmole Gypsum, 9.0395 mmole Sodium Chloride. (all expressed mmole per $\mathrm{kg}$ of groundwater). At the same time, cation exchange between $\mathrm{Na}^{+}$and $\mathrm{Ca}^{2+}$ occurred. During this process, $\mathrm{Na}^{+}$from the halite and sodium montmorillonite, dissolved into the water then underwent exchange with $\mathrm{Ca}^{2+}$ absorbed on the rock surface. $\mathrm{Ca}^{2+}$ from the rock surface dissolved into the water, and $\mathrm{Na}^{+}$was absorbed into the rock surface. $\mathrm{Na}^{+}$adsorption reaction played the leading role in the dissolution and the precipitation process and its precipitation amount reach to $2.49 \mathrm{mmol} / \mathrm{L}$, followed by, calcite, and aragonite, with amounts of $1.773 \mathrm{mmol} / \mathrm{L}$, and $1.77 \mathrm{mmol} / \mathrm{L}$, respectively.

Along the flow path line, the concentrations of $\mathrm{Na}^{+}, \mathrm{Cl}^{-}$, $\mathrm{Ca} \mathrm{SO}_{4}$ and gradually increased because of the increasing dissolution effects of halite, $\mathrm{Na}$ Mont., and gypsum, respectively, while the reduction of $\mathrm{CaCO}_{3}$ and $\mathrm{Ca}-\mathrm{Mg} \mathrm{CO} \mathrm{CO}_{3}$ could respectively be attributed to the precipitation of calcite, aragonite and dolomite. Dissolution of a large amount of halite and gypsum leads to increase the concentration of $\mathrm{Na}_{2} \mathrm{SO}_{4}{ }^{-}$and $\mathrm{Na} \mathrm{Cl}^{-}$, together with the reduction of $\mathrm{Ca}^{2+}$, caused the groundwater hydrochemical types to change from the $\mathrm{HCO}_{3} \cdot-\mathrm{Ca} \cdot \mathrm{Mg} \cdot \mathrm{Na}$ type to the $\mathrm{SO}_{4}{ }^{-}, \mathrm{Cl}+\mathrm{Na} \cdot \mathrm{Mg}-\mathrm{Ca}$ type.

When $\mathrm{CO}_{3}$ dissolved in water causes decrease the water $\mathrm{PH}$, leading to dissolution of gypsum. In addition, cation exchange process occurred between $\mathrm{Na}^{+}$andCa ${ }^{2+}$, during this process, dissolving high amount of $\mathrm{Na}^{+}$from the halite $(83.56$ $\mathrm{mmol} / \mathrm{L}$ ) into the water then exchange with $\mathrm{Ca}^{2+}$ absorbed on the clay surface. $\mathrm{Ca}^{2+}$ from the clay surface dissolved into the water causing formation of carbonate minerals (calcite, aragonite and dolomite), and $\mathrm{Na}^{+}$was absorbed into the rock surface. $\mathrm{Na}^{+}$adsorption reaction played the leading roles in the dissolution and the precipitation process, where $7.637 \mathrm{mmol} / \mathrm{L}$ exchange

$2 \mathrm{NaX}+\mathrm{Ca}^{2+} \leftrightarrow 2 \mathrm{Na}^{+}+\mathrm{CaX}_{2}$ and its precipitation amount was up to $-7.3 \mathrm{mmol} / \mathrm{L}$ calcium montmorillonite.

Dissolution of a large amount of halite and gypsum leads to increase in the concentration of $\mathrm{Na}_{2} \mathrm{SO}_{4}{ }^{-}$and $\mathrm{Na} \mathrm{Cl}$, together with the reduction of $\mathrm{Ca}^{2+}$, caused the groundwater hydrochemical types to change from the $\mathrm{HCO}_{3} \cdot-\mathrm{Ca} \cdot \mathrm{Mg} \cdot \mathrm{Na}$ type to the $\mathrm{SO}_{4}^{-}, \mathrm{Cl}{ }^{-} \mathrm{Na} \cdot \mathrm{Mg}-\mathrm{Ca}$ type. According to the groundwater analysis results and simulation results, we notes that the cation exchange is playing an important roles along path AA\ (path 1). From $N\left(\mathrm{Ca}^{2+}\right) / N\left(\mathrm{Na}^{+}\right)$relationship showed a clear upward trend, we conclude that the dissolution effects of chlorides and sulphate salts (halite and gypsum) were more significant than the precipitation of calcium carbonate minerals.

b) Profile $\left(\mathrm{BB}^{-}\right)$: The mass-balance transfer along the simulated path2 $\mathrm{BB}^{-}$in the middle part, fig. (6), halite accounted for the largest amount of dissolution, reaching $83.6 \mathrm{mmol} / \mathrm{L}$, followed by the dissolution of gypsum, which was $10.59 \mathrm{mmol} / \mathrm{L}$. At the same time, $1.876 \mathrm{mmole} \mathrm{K}-\mathrm{Mont}$, $0.0824 \mathrm{mmole}$ Dolomite, 0.01066 mmole Goethite, 1.39 mmole Calcite, 0.00533 Hematite also dissolved on different levels,. The cation exchange process between $\mathrm{Na}+$ and $\mathrm{Ca}^{2+}$ also occurred along simulated path $\mathrm{BB} \backslash$ (path 2). Where Calcium montmorillonite accounted for the largest amount of precipitation, $7.28 \mathrm{mmol} / \mathrm{L}$. along the water flow path, $\mathrm{CO}_{2}$ dissolved in large volume as a result of dissolving of carbonate minerals; (calcite, aragonite and dolomite), caused the reduction of the $\mathrm{pH}$, and also the dissolution of gypsum.

A large amounts of gypsum and dolomite dissolution in the water solution leads to increase in $\mathrm{Ca}^{2+}$ also, K- Mont dissolved, which theoretically should have left $\mathrm{HCO}_{3}-\mathrm{Al}(\mathrm{OH})_{4}-$ and $\mathrm{SiO}_{2}$ in the groundwater. However, they were quickly converted into calcium montmorillonite, which meant that dissolution of K- Mont., gypsum, dolomite, calcite and aragonite led to the precipitation of calcium montmorillonite.

In addition, cation exchangeprocess occurred between $\mathrm{Na}^{+}$ andCa ${ }^{2+}$, during this process. Dissolution of a large amount of $\mathrm{Na}^{+}$from the halite $(83.56 \mathrm{mmol} / \mathrm{L})$ dissolved into the water then exchange with $\mathrm{Ca}^{2+}$ absorbed on the clay surface, also dissolution of $\mathrm{Ca}^{2+}$ from the rock surface into the water causing formation of carbonate salts (calcite, aragonite and dolomite) and $\mathrm{Na}^{+}$was absorbed on the clay surface. $\mathrm{Na}^{+}$ adsorption reaction played the leading roles in the dissolution and the precipitation process, where $7.637 \mathrm{mmol} / \mathrm{L}$ exchange

$2 \mathrm{NaX}+\mathrm{Ca}^{2+} \leftrightarrow 2 \mathrm{Na}^{+}+\mathrm{CaX}_{2}$ and its precipitation amount was up to $-7.3 \mathrm{mmol} / \mathrm{L}$ calcium montmorillonite.

Dissolution of a large amount of halite and gypsum leads to increase in the concentration of $\mathrm{Na}_{2} \mathrm{SO}_{4}{ }^{-}$and $\mathrm{Na} \mathrm{Cl}$, together with the reduction of $\mathrm{Ca}^{2+}$, caused the groundwater hydrochemical types to change from the $\mathrm{HCO}_{3}-\mathrm{Ca} \cdot \mathrm{Mg} \cdot \mathrm{Na}$ type to the $\mathrm{SO}_{4}^{-}, \mathrm{Cl}{ }^{-} \mathrm{Na} \cdot \mathrm{Mg}-\mathrm{Ca}$ type. According to the groundwater analysis results and simulation results, we determined that the cation exchange had more effects along path $\mathrm{BB} \backslash 2$ and $N\left(\mathrm{Ca}^{2++}\right) / N\left(\mathrm{Na}^{+}\right)$relationship showed a clear 
downward trend, which helped us to conclusion that the dissolution effects of halite and gypsum are more significant than the precipitation of calcium montmorillonite.

c) Profile (C): The mass-balance transfer along this profile fig. (7), precipitation -1.919 mmole of Aragonite, -0.0107 mmole of Goethite, -1.9 Calcite and -0.00529 mmole of Hematite. and dissolution of 1.2446 mmole K-Mon,. 50092 mmole Dolomite, 5.095 mmole Gypsum, 18.66mmole Sodium Chloride, and $3.579 \mathrm{mmolecation}$ exchange reactions between $\mathrm{Na}+$ and $\mathrm{Ca}^{2+}$ also occurred along simulated path $3 \mathrm{CC}^{\prime}$.

Along the water flow path, $\mathrm{CO}_{2}$ dissolved in large volume, coupled with the dissolution of dolomite, which together caused the reduction of the $\mathrm{pH}$, and in leads to the dissolution of gypsum. Similar to the case of simulated path 2, Gypsum and dolomite dissolution in the aqueous solution should have caused increase in $\mathrm{Ca}^{2+}$ and $\mathrm{CO}_{3}{ }^{2-}$ in addition to cation exchange, a large amount of calcite precipitation occurred. Thus, we came to the assumption that $\mathrm{Ca}^{2+}$ and $\mathrm{CO}_{3}{ }^{2-}$ together responsible for formation of calcite and aragonite; that is to say, gypsum and dolomite caused calcite precipitation, also amounts of $\mathrm{Mg}^{2+}$ were left in the water. Dissolution of a large amount of halite and gypsum leads to increase in the concentration of $\mathrm{Na}_{2} \mathrm{SO}_{4}{ }^{-}$and $\mathrm{Na} \mathrm{Cl}^{-}$, together with the reduction of $\mathrm{CaCO}_{3}$, caused the hydrochemical groundwater types to change from the $\mathrm{HCO}_{3}^{-}, \mathrm{Ca} \cdot \mathrm{Mg} \cdot \mathrm{Na}$ type to the $\mathrm{SO}_{4}^{-}, \mathrm{Cl}^{-} \mathrm{Na} \cdot \mathrm{Mg}-\mathrm{Ca}$ type.

We notes determined that the cation exchange had significant effects along path $\mathrm{CC} \backslash$ (path 3) and $N\left(\mathrm{Ca}^{2++}\right) /$ $N\left(\mathrm{Na}^{+}\right)$relationships showed a clear downward trend, which helped us to conclude that the dissolution effects of halite and gypsum were greater than the precipitation effects of carbonate salts ( calcite and aragonite).

Conclusionnaly that, the predominant reactions for all profiles appear to be dissolution of Sodium Chloride, Gypsum, Dolomite, Rhodochr and Vivianit. and precipitation of Ca-mon, Aragonite, Goethite with different values. So there is increase in salinity in all profiles in the same direction of groundwater flow, and change in hydrochemical groundwater types from the $\mathrm{HCO}_{3} \cdot \mathrm{Ca} \cdot \mathrm{Mg} \cdot \mathrm{Na}$ type to the $\mathrm{SO}_{4}{ }^{-}, \mathrm{Cl}^{-} \mathrm{Na} \cdot \mathrm{Mg}-\mathrm{Ca}$ type.

Even through primary silicate minerals (clay minerals) predominate in the mineralogy of the Pliocene aquifer in Wadi El Natrunarea, the mass balance modeling indicates that reactions with these minerals are secondary to those of the more reaction carbonate, sulfate and chlorides. The concentration ofsodium and chloride in the Pliocene aquifer shows that, $\mathrm{Na}^{+}$ion exceeded $\mathrm{Cl}^{-}$in all samples. So, ion exchange and dissolution are the main processes along the flow path respect to the Na-Clwater type in this aquifer. This reaction agreement with the sequence of cations $\left(\mathrm{Na}^{+}>\mathrm{Ca}^{++}>\right.$ $\left.\mathrm{Mg}^{++}\right),\left(\mathrm{Na}^{+}>\mathrm{Mg}^{++}>\mathrm{Ca}^{++}\right)$and anions $\left(\mathrm{Cl}^{-}>\mathrm{SO}_{4}{ }^{--}>\mathrm{HCO}_{3}{ }^{-}\right)$. From these profiles we notes that the groundwater types change from less advanced stage of mineralization $\left(\mathrm{HCO}_{3}{ }^{-}>\right.$ $\left.\mathrm{SO}_{4}{ }^{-}>\mathrm{Cl}^{-}\right)$to more advanced stage of mineralization $\left(\mathrm{Cl}^{-}>\right.$ $\mathrm{SO}_{4}{ }^{-}>\mathrm{HCO}_{3}{ }^{-}$)

\section{Conclusions}

The aim of this paper is to evaluate the geo-chemical processes controlling the composition of ground waters, using hydrogeochemical models and considering the final composition as the result of the interaction between groundwater and rocks. water-rock interactions in Wadi El Natrun area were simulated and examined during hydrogeochemical modeling (NETPATH program), and the following conclusions were drawn:

1. Geochemical modeling (Netpath) shows that the special type of composition responsible for the waters mineralization can be explained by dissolution of large amounts of halite and gypsum leads to increase in the concentration of $\mathrm{Na}_{2} \mathrm{SO}_{4}^{-}$and $\mathrm{Na} \mathrm{Cl}^{-}$, together with the precipitation of carbonate minerals leads to reduction of $\mathrm{CaCO}_{3}$.

2. The changes in groundwater types and chemical composition from the $\mathrm{HCO}_{3}, \mathrm{Ca} \cdot \mathrm{Mg} \cdot \mathrm{Na}$ type to the $\mathrm{SO}_{4}^{-}, \mathrm{Cl}^{-} \mathrm{Na} \cdot \mathrm{Mg}-\mathrm{Ca}$ type result from the combined actions of aforementioned dissolutions and precipitations process, as well as cation exchange reactions.

3. The reaction of cation exchange had significant effects along pathes 1,2 and 3 .

4. The relationships between $\mathrm{N}\left(\mathrm{Ca}^{2++}\right) / \mathrm{N}\left(\mathrm{Na}^{+}\right)$showed a clear downward trend in both simulated path 2 and 3 while upward trend in the simulated path 1 in the south sector, which helped us to conclude that the dissolution effects of halite and gypsum are more significant than the precipitation of calcium carbonate minerals.

\section{References}

[1] Abdel Baki, A. A. (1983): Hydrogeological and hydrogeochemical studies on the area west of Rosetta branch and south El Naser canal. Ph. D. Thesis, Fac. Sci., Ain Shams Univ., Cairo, Egypt, 156 p.

[2] ASTM, American Society for testing and material (2002). In "water and environmental technology". annual book of ASYM standars, Sec. 11, Vol. 11.01 and 11.02, West Conshohocken, U.S.A.

[3] Bertolo, R., Hirata, R., and Sracek, O. 2006. Geochemistry and geochemical modeling of unsaturated zone in a tropical region in Urânia, São Paulo state, Brazil. Journal of Hydrology, $329 \quad(1-2), \quad 49-62 . \quad$ [doi: 10.1016/j.jhydrol.2006.02.001].

[4] Diab, M. Sh., Gad, M. I., Abd-el Baki, and El Sheihk, A. A. (2002): Study the effect of new reclamation projects on the groundwater system in the area northwest Wadi El Natrun and south El Nasr by using mathematical modeling. Final program and Abstracts at the Third International Conference, Groundwater level control Inside Urbanized Areas, Fac. Eng., Mansoura Univ., El Mansoura, December, 17-19, 2002.

[5] El- Abd, E. A. (2005): The Geological impact on the water bearing formations in the area south west Nile Delta, Egypt., Ph. D. Thesis, Geol. Depart. Fac. Sci; Menoufia Univ; 319 p. 
[6] Lyon WB, Bird DA. (1995): Geochemistry of the Madeira River Brazil: comparison of seasonal weathering reactions using a mass balance approach. Journal of South American Earth Science; Volume 8, Number 1. Elsevier pp: 97-101.

[7] Park, S. C., Yun, S. T., Chae, G. T., Yoo, I. S., Shin, K. S., Heo, C. H., and Lee, S. K. 2005. Regional hydrochemical study on salinization of coastal aquifers, western coastal area of South Korea. Journal of Hydrology, 313 (3-4), 182-194. [doi:10.1016/j.jhydrol.2005.03.001].

[8] Plummer, L. N. Parhurst, D. L., Fleming, G. W. and Dunkel, S. A. (1988): A computer program incorporating pitzers equations for calculation of geochemical reactions in brines. U.S. Geol. Surv., Water Resour. Inv. Rep. p. 88-4153.

[9] Plummer NP, Prestemon EC, Parkhurst DL. (1994). An interactive code NETPATH for modelling net geochemical reactions along a flow path_version 2.0. United States Geological Survey, 120 p.

[10] Sharif, M. U., Davis, R. K., Steele, K. F., Kim, B., Kresse, T. M., and Fazio, J. A. 2008. Inverse geochemical modeling of groundwater evolution with emphasis on arsenic in the
Mississippi River Valley alluvial aquifer, Arkansas (USA). Journal of Hydrology, 350 (1-2), 41-55. [doi:10.1016/j.jhydrol.2007.11.027.

[11] Soulsby C, Chen M, Ferrier RC, Helliwell RC, Jenkins R, Harriman R. (1998). Hydrogeochemistry of shallow groundwater in an upland Scottish catchment. Hydrological Process; 12, pp 1111-1117.

[12] Sun, Y. Q., Qian, H., and Wu, X. H. 2007. Hydrogeochemical characteristics of groundwater depression cones in Yinchuan City, Northwest China. Chinese Journal of Geochemistry, 26 (4), 350-355. [doi:10.1007/s11631-007-0350-x].

[13] Wang, P. M., Anderko, A., Springer, R. D., Kosinski, J. J., and Lencka, M. M. 2010. Modeling chemical and phase equilibria in geochemical systems using a speciation-based model. Journal of Geochemical Exploration, 106(1-3), 219-225. [doi:10.1016/j.gexplo.2009.09.003].

[14] Xu, Z. H., Li, Y. F., Jiang, L., Hou, G. C., and Hu, A. Y. 2009. Geochemical modeling of Huanhe water-bearing layers in South Ordos Basin. Journal of Arid Land Resources and Environment, 23 (9). 